\title{
Estimates of Genetic Component of Variation in Muskmelon (Cucumis melo L.)
}

\author{
Koushik Saha $^{1 *}$, Subhalaxmi Mishra ${ }^{2}$, H. Choudhary ${ }^{1}$ and Sourav Mahapatra ${ }^{1}$ \\ ${ }^{1}$ Division of Vegetable Science, Indian Agriculture Research Institute, \\ New Delhi-110012, India \\ ${ }^{2}$ Department of Vegetable and Spice Crop, Uttar Banga Krishi Viswavidyalaya-736165, India \\ *Corresponding author
}

\section{A B S T R A C T}

\section{Keywords}

Muskmelon, Half-diallel; dominance component of genetic variance, Additive component of genetic variance, Additive gene action, Dominant gene action

Article Info

Accepted:

08 June 2018

Available Online: 10 July 2018
A study of twenty one $\mathrm{F}_{1}$ hybrids of Muskmelon (Cucumis melo L.) in a half-diallel set involving seven parents showed over-dominance and low narrow-sense heritability for all the characters except node no of first female flower, average fruit weight, first fruit harvest and yield per plant. In all these characters, the dominance component of genetic variance $\left(\mathrm{H}_{1}\right)$ was higher than the additive component of genetic variance (D) indicating predominance of dominant gene action over additive gene action and commercial exploitation of heterosis for improvement of these traits.

\section{Introduction}

Muskmelon (Cucumis melo L., $2 \mathrm{n}=2 \mathrm{x}=24$ ) is one of the most nutritive and commercially important cucurbit extensively cultivated in hot and arid areas of Uttar Pradesh, Punjab, Rajasthan, Madhya Pradesh, Bihar and Karnataka and being grown in cultivable land as well as in marginal land of riverbed areas. The centre of origin of muskmelon was earlier considered as African continent but recent studies showed that cucumber and muskmelon both are of Asian origin and wide diversity of wild species of Cucumis melo L. exists in
India and China (Sebastian et al 2010). Cucumis melo L. is considered as one of the most diverse and highly polymorphic species in Cucurbitaceae family (Danin-Poleg, et al., 2001, Decker-Walters, et al., 2002) and it comprises of a large number of botanical varieties or horticultural groupings which may be consequence of higher genetic diversity in this species (Mliki et al., 2001). The improvement programme of Muskmelon is based mainly on exploiting natural sources of germplasm by means of selection and hybridization followed by selection. 
For development of promising high yielding varieties, the identification of genetically superior plants is an important pre-requisite. The knowledge of gene effects for different traits is of prime importance before starting a breeding programme. Determination of the most suitable breeding method and selection strategy for improvement of a trait would depend on the knowledge of gene actions operating in breeding population. In plant breeding, gene action is usually measured in terms of components of genetic variances or combining ability variances and effects. In heterosis breeding, a knowledge of combining ability, gene action and relative amount of additive and non-additive components of genetic variance present in cross combination helps to determine the feasibility of its utilization and identification of best combiners. Selection and hybridization are two basic methods for crop improvement. The success of selection mainly depends upon the extent of genetic variability present it. Therefore, a higher genetic base should be utilized for faster and higher magnitude of success. Utilization of divergent germplasm in hybridization creates such broad genetic base (Singh, 1998).

A detailed knowledge about the magnitude and nature of genetic variation in a specific population is of prime importance for the effective prediction of the most effective breeding programme. The numerical analysis of diallel provides detailed account of additive and dominance components and the allied statistics. The genetics largely depends upon the relative magnitude of these two components. The genetic model on which the analysis of diallel tables is based involve certain assumptions viz. (i) segregation is diploid; (ii) there are only environmental differences between reciprocal crosses; (iii) absence of epistasis; (iv) the parents are homozygous; (v) there are no multiple alleles (vi) that the genes are independently distributed and that there is no genotype interaction with locations and years (Walton, 1968).

In spite of exhibiting considerable amount of genetic diversity with respect to different characters little attention has been given for improvement of this crop. Hence, an attempt was made to investigate the gene action (inheritance pattern) of yield and yield attributing traits.

\section{Materials and Methods}

The present investigation was carried out during spring summer and kharif season of 2015 at research farm of Division of Vegetable Science of Indian Agricultural Research Institute, New Delhi. Seven genetically diverse inbreds of Muskmelon viz, DHM-163 ( $\left.\mathrm{P}_{1}\right)$, DHM-162 ( $\left.\mathrm{P}_{2}\right)$, DMM-159 $\left(\mathrm{P}_{3}\right)$, DCM-31 $\left(\mathrm{P}_{4}\right)$, Pusa Madhuras $\left(\mathrm{P}_{5}\right)$, Kashi Madhu $\left(\mathrm{P}_{6}\right)$ and Hara Madhu $\left(\mathrm{P}_{7}\right)$ were crossed in 7 x 7 half-diallel (excluding reciprocals) mating scheme (Hayman, 1954). The resulting $21 \mathrm{~F} 1$ hybrids along with 7 parental lines were evaluated in a randomized block design with three replications. The seeds were sown in rows of $2.5 \mathrm{~m}$ with $0.75 \mathrm{~m}$ spacing between the plants. All the recommended package of practices was followed to grow a successful crop. Out of 12 plants, 10 were marked for taking observations. Observations on individual plant basis were recorded on nine quantitative characters viz. days to first male flower opening, days to pistillate flower opening, node to first male flower opening, node to first pistillate flower opening, node to first fruit set, number of fruits per plant, average fruit weight, fruit length, fruit diameter, flesh thickness, cavity width, days from pollination to fruit harvest, days to first fruit harvest, vine length, number of primary branches per plant and set harvest, fruit length $(\mathrm{cm})$, fruit diameter $(\mathrm{cm})$, average fruit weight $(\mathrm{g})$, number of fruits per plant, vine length $(\mathrm{m})$ and total fruit yield per plant $(\mathrm{kg})$. Gene action 
was studied by the diallel method of numerical approach given by Hayman (1954). If the estimates of average degree of dominance [(H1/D) $1 / 2$ ] is ' 0 ' denote no dominance, 0 to 1 , partial dominance; 1 , complete dominance and $>1$, over dominance. The maximum values of $\mathrm{H} 2 / 4 \mathrm{H} 1$ shall be 0.25 when $\mathrm{u}=\mathrm{v}=0.05$. If the relative frequency of dominant and recessive genes $\left[(4 \mathrm{DH} 1)^{1 / 2}+\mathrm{F} /(4 \mathrm{DH} 1)^{1 / 2}-\mathrm{F}\right]$ in parents $=1$, means nearly equal proportion i.e. symmetrical distribution; $\mathrm{u}=\mathrm{v}=0.5$. Any deviation from 1 shows asymmetry of distribution $(u>v)$ as $>1$ refers to excess of dominant genes and minority of recessive genes $(\mathrm{u}>\mathrm{v})$ and $<1$ means minority of dominant genes and excess of recessive $(u<$ v).

\section{Results and Discussion}

The estimates of genetic components of variation and various statistical parameters for different characters were represented in Table 1. The genetic component of variation for days to first pistillate flower anthesis, the estimates of $\mathrm{H}_{1}, \mathrm{H}_{2}$ and $\mathrm{h}^{2}$ were highly significant viz $\mathrm{D}$ was non-significant. The value of $\mathrm{H}_{1}$ was more than D, which signify that dominant genes were more than additive genes. The environmental influence $(\mathrm{E})$ on the inheritance of this was significant. The mean degree of dominance $\left(\mathrm{H}_{1} / \mathrm{D}\right)^{1 / 2}$ was lesser than one $(0.76)$ and indicated role of partial dominance for this trait. The proportion of genes with positive and negative effects $\left(\mathrm{H}_{2} / 4 \mathrm{H}_{1}\right)$ in the parents was found to be less than $0.25(0.23)$, denoting asymmetry at the loci showing dominance. The proportion of dominant and recessive gene as indicated by $\left[(4 \mathrm{DH} 1)^{1 / 2}+\mathrm{F} /\right.$ $\left.(4 \mathrm{DH} 1)^{1 / 2}-\mathrm{F}\right]$ was 1.49 while the group of genes, which controlled the characters $\left(\mathrm{h}^{2} / \mathrm{H}^{2}\right)$ and exhibited dominance was 2.30. Narrow sense heritability being $75.77 \%$ showed preponderance of partial dominance.

Results pertaining to days to first fruit harvest the estimates of $\mathrm{H}_{2}, \mathrm{E}$ and $\mathrm{h}^{2}$ were highly significant. The value of $\mathrm{H}_{1}$ was lesser than $\mathrm{D}$, suggesting the presence of additive genes in parents. The positive value of $\mathrm{F}$ showed dominant alleles was more frequent. The mean degree of dominance $\left(\mathrm{H}_{1} / \mathrm{D}\right)^{1 / 2}$ being 2.37 indicating over-dominance. The proportion of genes with positive and negative effects $\left(\mathrm{H}_{2} / 4 \mathrm{H}_{1}\right)$ was 0.25 , showing dominance. The proportion of dominant and recessive genes $\left[\left(4 \mathrm{DH}_{1}\right)^{1 / 2}+\mathrm{F} /\left(4 \mathrm{DH}_{1}\right)^{1 / 2}-\mathrm{F}\right]$ in the parents was 0.59 , while the group of dominant genes $\left(\mathrm{h}^{2} / \mathrm{H}^{2}\right)$ was 2.10 . Narrow sense heritability being $11.08 \%$ exhibited predominance of nonadditive gene action.

Results pertaining to fruit length the estimates of $\mathrm{H}^{2}, \mathrm{E}$ and $\mathrm{h}^{2}$ were highly significant. The value of $\mathrm{H}_{1}$ was more than $\mathrm{D}$, exhibiting nonadditive gene action. The positive $\mathrm{F}$ value indicated more prevalence of dominant alleles in parents. The mean degree of dominance $\left(\mathrm{H}_{1} / \mathrm{D}\right)^{1 / 2}$ was 2.03 indicating over-dominance. While the proportion of genes with positive and negative effects $\left(\mathrm{H}_{2} / 4 \mathrm{H}_{1}\right)$ in parents was found to be 0.21 denoting asymmetry at loci showing dominance. The proportion of dominant and recessive genes $\left[\left(4 \mathrm{DH}_{1}\right)^{1 / 2}+\mathrm{F} /\right.$ $\left.\left(4 \mathrm{DH}_{1}\right)^{1 / 2}-\mathrm{F}\right]$ in parents was 1.48. Narrow sense heritability $(20.49 \%)$ showed preponderance of non-additive gene action.

The genetical parameters like $\mathrm{H}_{2}, \mathrm{E}, \mathrm{h}^{2}, \mathrm{~F}$ were significant for fruit diameter. The value of $\mathrm{H} 1$ was greater than $\mathrm{D}$ indicating presence of non-additive genes. The positive value of $\mathrm{F}$ indicated that the dominant allele were more frequent in parents. The mean degree of dominance $\left(\mathrm{H}_{1} / \mathrm{D}\right)^{1 / 2}$ being 2.64 exhibited overdominance. The proportion of genes with positive and negative effects $\left(\mathrm{H}_{2} / 4 \mathrm{H}_{1}\right)$ was noted 0.22 indicating asymmetry at loci showing dominance. The proportion of dominant and recessive genes $\left[(4 \mathrm{DH} 1)^{1 / 2}+\mathrm{F} /\right.$ $\left.\left(4 \mathrm{DH}_{1}\right)^{1 / 2}-\mathrm{F}\right]$ in the parents was 0.53 whereas the number of dominant group of genes $\left(\mathrm{h}^{2} / \mathrm{H}_{2}\right)$ was 0.75 . Narrow sense heritability $(13.04 \%)$ showed preponderance of additive 
type of gene action for this trait. For fruit weight, the estimated value of $\mathrm{H}_{1}$ was lesser than $\mathrm{D}$ which revealed that additive genes were more than non-additive genes. The mean degree of dominance $\left(\mathrm{H}_{1} / \mathrm{D}\right)^{1 / 2}$ being 1.43 showed over-dominance. The proportion of genes with positive and negative effects $\left(\mathrm{H}_{2} / 4 \mathrm{H}_{1}\right)$ was 0.21 , which denotes asymmetry at loci. The proportion of dominance and recessive genes $\left[\left(4 \mathrm{DH}_{1}\right)^{1 / 2}+\mathrm{F} /\left(4 \mathrm{DH}_{1}\right)^{1 / 2}-\mathrm{F}\right]$ was 1.00 whereas number of group of genes exhibiting dominance and controlling character was 1.50. The narrow sense heritability $(29.69 \%)$ indicated the dominant type of gene action for expression of this character.

The genetic component of variation for number of fruits per plant viz. $\mathrm{H}_{2}, \mathrm{~h}_{2}$ and $\mathrm{E}$ were highly significant. The value of $\mathrm{H}_{1}$ was more than $\mathrm{D}$ which showed more prevalence of dominant genes. The degree of dominance $\left(\mathrm{H}_{1} / \mathrm{D}\right)^{1 / 2}$ was 1.77 revealed role of overdominance. The proportion of genes with positive and negative effects $\left(\mathrm{H}_{2} / 4 \mathrm{H}_{1}\right)$ was 0.22 exhibiting dominance. The proportion of dominant and recessive genes [(4DH1) $1 / 2+\mathrm{F} /$ $\left.\left(4 \mathrm{DH}_{1}\right)^{1 / 2}-\mathrm{F}\right]$ was 1.11 whereas the number of group of genes $\left(\mathrm{h}^{2} / \mathrm{H}_{2}\right)$ which showed dominance was 1.65. Narrow sense heritability $(20.14 \%)$ indicated non-additive gene action.

For vine length, the estimated value of $\mathrm{H}^{1}, \mathrm{H}_{2}$ $\mathrm{E}$ and $\mathrm{h}^{2}$ were highly significant. The estimated value of $\mathrm{H}_{1}$ was greater than $\mathrm{D}$ which revealed that non-additive genes were more than additive genes. Positive value of $\mathrm{F}$ indicated predominance of dominant alleles. The mean degree of dominance $\left(\mathrm{H}_{1} / \mathrm{D}\right)^{1 / 2}$ being 0.98 showed partial-dominance. The proportion of genes with positive and negative effects $\left(\mathrm{H}_{2} / 4 \mathrm{H}_{1}\right)$ was 0.22 , which denotes asymmetry at loci. The proportion of dominance and recessive genes $\left[\left(4 \mathrm{DH}_{1}\right)^{1 / 2}+\mathrm{F} /\right.$ $\left.\left(4 \mathrm{DH}_{1}\right)_{1 / 2}-\mathrm{F}\right]$ was 1.82 whereas number of group of genes exhibiting dominance and controlling character was 0.39 . The narrow sense heritability $(68.30 \%)$ indicated the partial dominant type of gene action for expression of this character.

Results pertaining to components of genetic variation for total yield per plant revealed that estimate of $\mathrm{H}_{2}$ and $\mathrm{E}$ were highly significant. The value of $\mathrm{H}_{1}$ was lesser than $\mathrm{D}$ indicating the presence of more additive genes. The value of $\left(\mathrm{H}_{1} / \mathrm{D}\right)^{1 / 2}$ was higher (5.27) indicating over-dominance. The proportion of genes with positive and negative effects $\left(\mathrm{H}_{2} / 4 \mathrm{H}_{1}\right)$ in parents was found to be 0.24 (less than 0.25 ), which denoted asymmetry at loci showing dominance. The proportion of dominance and recessive genes $\left[\left(4 \mathrm{DH}_{1}\right)^{1 / 2}+\mathrm{F} /\left(4 \mathrm{DH}_{1}\right)^{1 / 2}-\mathrm{F}\right]$ was 0.51 . The number of group of genes $\left(\mathrm{h}^{2} / \mathrm{H}_{2}\right)$ exhibiting dominance and controlling the character was 2.00. The narrow sense heritability $(2.83 \%)$ indicated that nonadditive type of gene action played an important role in the inheritance of this trait.

Results pertaining to components of genetic variation for node no of pistillate flower opening, flesh thickness and cavity width revealed that the value of $\left(\mathrm{H}_{1} / \mathrm{D}\right)^{1 / 2}$ was higher $(1.08,1.14$ and 1.04) indicating overdominance. The proportion of genes with positive and negative effects $\left(\mathrm{H}_{2} / 4 \mathrm{H}^{1}\right)$ in parents was found to be $0.21,0.21$ and 0.19 (less than 0.25 ), which denoted asymmetry at loci showing dominance. The narrow sense heritability $(31.06 \%, 32.59 \%$ and $45.94 \%)$ indicated that non-additive type of gene action played an important role in the inheritance of these traits.

Results pertaining to components of genetic variation for no of primary branches revealed that estimate of $\mathrm{H}_{2}, E$ and $\mathrm{h}^{2}$ were highly significant. The value of $\mathrm{H}_{1}$ was higher than $\mathrm{D}$ indicating the presence of more additive genes. 
Table.1 Estimates of genetic components of variation and various statistical parameters for yield related traits

\begin{tabular}{|c|c|c|c|c|c|c|c|c|}
\hline Genetic parameter & $\begin{array}{c}\text { Days to } \\
\text { first male } \\
\text { flower } \\
\text { opening }\end{array}$ & $\begin{array}{l}\text { Days to first } \\
\text { pistillate } \\
\text { flower } \\
\text { opening }\end{array}$ & $\begin{array}{l}\text { Node to first } \\
\text { male flower } \\
\text { opening }\end{array}$ & $\begin{array}{l}\text { Node to first } \\
\text { pistillate } \\
\text { flower } \\
\text { opening }\end{array}$ & $\begin{array}{l}\text { Node to } \\
\text { first fruit } \\
\text { set }\end{array}$ & $\begin{array}{l}\text { Number of } \\
\text { fruits / plant }\end{array}$ & $\begin{array}{c}\text { Avg fruit } \\
\text { weight }(\mathrm{kg})\end{array}$ & $\begin{array}{c}\text { Fruit } \\
\text { length }(\mathrm{cm})\end{array}$ \\
\hline $\mathrm{D}$ (Additive effect) & 0.23 & 0.19 & 0.03 & 0.70 & 0.90 & 0.04 & 0.06 & 0.18 \\
\hline $\mathrm{SE} \pm$ & 0.37 & 0.25 & 0.01 & 0.04 & 0.04 & 0.04 & 0.00 & 0.30 \\
\hline $\mathrm{F}$ (Gene distribution) & $10.66^{* *}$ & $16.88 * *$ & $0.37 * *$ & $0.91 * *$ & $1.63 * *$ & 0.22 & 0.03 & 1.37 \\
\hline SE \pm & 1.04 & 0.71 & 0.04 & 0.13 & 0.12 & 0.12 & 0.01 & 0.85 \\
\hline $\mathrm{H}_{1}$ & $6.80 * *$ & $5.05 * *$ & $0.26^{*}$ & $0.67 * *$ & 0.40 & 0.08 & 0.00 & 1.06 \\
\hline $\mathrm{SE} \pm$ & 2.49 & 1.69 & 0.10 & 0.23 & 0.28 & 0.28 & 0.02 & 2.03 \\
\hline $\mathrm{H}_{2}$ & $9.96 * *$ & $9.71 * *$ & $0.28 *$ & $14.06 * *$ & $1.18^{* *}$ & $0.69 * *$ & 0.07 & $5.39 *$ \\
\hline $\mathrm{SE} \pm$ & 2.50 & 1.70 & 0.10 & 0.30 & 0.28 & 0.28 & 0.02 & 2.04 \\
\hline$h^{2}$ & $8.31 * *$ & $8.95 * *$ & $0.23 *$ & $0.93 * *$ & $0.95 * *$ & $0.62 * *$ & 0.06 & $4.49 * *$ \\
\hline $\mathrm{SE} \pm$ & 2.21 & 1.50 & 0.09 & 0.27 & 0.25 & 0.25 & 0.01 & 1.80 \\
\hline $\mathrm{E}$ (Environmental effect) & $15.46^{* *}$ & $20.56 * *$ & 0.04 & 0.23 & $1.31 * *$ & $1.02 * *$ & 0.09 & $2.86 *$ \\
\hline $\mathrm{SE} \pm$ & 1.48 & 1.01 & 0.10 & 0.18 & 0.17 & 0.17 & 0.01 & 1.21 \\
\hline$\left(\mathrm{H}_{1} / \mathrm{D}\right)^{1 / 2}$ & 0.97 & 0.76 & 0.86 & 1.08 & 0.85 & 1.77 & 1.43 & 2.03 \\
\hline $\mathrm{H}_{2} / 4 \mathrm{H}_{1}$ & 0.21 & 0.23 & 0.21 & 0.22 & 0.20 & 0.22 & 0.21 & 0.21 \\
\hline$\left(\left(4 \mathrm{DH}_{1}\right)^{\wedge} .5+\mathrm{F}\right) /\left(\left(4 \mathrm{DH}_{1}\right)^{\wedge} .5-\mathrm{F}\right)$ & 1.98 & 1.49 & 2.36 & 1.21 & 1.34 & 1.11 & 1.00 & 1.48 \\
\hline $\mathrm{h}^{2} / \mathrm{H}_{2}$ & 1.86 & 2.30 & 0.17 & 0.25 & 1.38 & 1.65 & 1.50 & 0.64 \\
\hline $\mathrm{r}$ & 0.54 & 0.94 & 0.57 & -0.72 & -0.09 & -0.65 & -0.82 & 0.31 \\
\hline Heritability (narrow sense) & 72.38 & 75.77 & 71.62 & 31.06 & 45.81 & 20.14 & 29.69 & 20.49 \\
\hline
\end{tabular}


Table.2 Estimates of genetic components of variation and various statistical parameters for yield related traits

\begin{tabular}{|c|c|c|c|c|c|c|c|c|}
\hline Genetic parameter & $\begin{array}{c}\text { Fruit } \\
\text { diameter } \\
(\mathrm{cm})\end{array}$ & $\begin{array}{c}\text { Flesh } \\
\text { thickness } \\
(\mathrm{cm})\end{array}$ & $\begin{array}{l}\text { Cavity } \\
\text { width } \\
(\mathrm{cm})\end{array}$ & $\begin{array}{c}\text { Days from } \\
\text { pollination to } \\
\text { harvest }\end{array}$ & $\begin{array}{l}\text { Days to first } \\
\text { fruit harvest }\end{array}$ & Vine length(m) & $\begin{array}{c}\text { No of primary } \\
\text { branches }\end{array}$ & Yield/plant \\
\hline $\mathrm{D}$ (Additive effect) & 0.12 & 0.02 & 0.04 & 0.55 & 1.42 & 0.00 & 0.10 & 0.05 \\
\hline $\mathrm{SE} \pm$ & 0.08 & 0.01 & 0.05 & 0.62 & 0.92 & 0.01 & 0.05 & 0.06 \\
\hline $\mathrm{F}$ (Gene distribution) & $0.52 * *$ & 0.19 & $0.92 * *$ & $13.34 * *$ & 4.69 & $0.28 * *$ & 0.20 & 0.07 \\
\hline $\mathrm{SE} \pm$ & 0.21 & 0.02 & 0.13 & 1.76 & 2.61 & 0.03 & 0.15 & 0.17 \\
\hline $\mathrm{H}_{1}$ & 0.62 & 0.02 & 0.09 & -1.49 & -5.72 & $0.16^{*}$ & 0.37 & -0.24 \\
\hline $\mathrm{SE} \pm$ & 0.51 & 0.06 & 0.31 & 4.23 & 6.27 & 0.07 & 0.37 & 0.40 \\
\hline $\mathrm{H}_{2}$ & $3.62 * *$ & $0.25 * *$ & $0.99 * *$ & $11.76 * *$ & $26.22 * *$ & $0.27 * *$ & $1.83 * *$ & $1.93 * *$ \\
\hline $\mathrm{SE} \pm$ & 0.51 & 0.06 & 0.31 & 4.25 & 6.29 & 0.07 & 0.37 & 0.40 \\
\hline$h^{2}$ & $3.15 * *$ & $0.21 *$ & $0.77 * *$ & $10.80 * *$ & $26.00 * *$ & $0.23 * *$ & $1.48 * *$ & 1.83 \\
\hline $\mathrm{SE} \pm$ & 0.45 & 0.05 & 0.27 & 3.74 & 5.54 & 0.06 & 0.33 & 0.36 \\
\hline $\mathrm{E}$ (Environmental effect) & $2.35^{* *}$ & $0.19 * *$ & 0.00 & $9.87 * *$ & $54.49 * *$ & $0.09 *$ & $2.51 * *$ & $3.66 * *$ \\
\hline $\mathrm{SE} \pm$ & 0.23 & 0.03 & 0.18 & 2.51 & 3.72 & 0.04 & 0.22 & 0.24 \\
\hline$\left(\mathrm{H}_{1} / \mathrm{D}\right)^{1 / 2}$ & 2.64 & 1.14 & 1.04 & 0.94 & 2.37 & 0.98 & 10.80 & 5.27 \\
\hline $\mathrm{H}_{2} / 4 \mathrm{H}_{1}$ & 0.22 & 0.21 & 0.19 & 0.23 & 0.25 & 0.22 & 0.20 & 0.24 \\
\hline $\begin{array}{l}\left(\left(4 \mathrm{DH}_{1}\right)^{\wedge} .5+\mathrm{F}\right) /\left(\left(4 \mathrm{DH}_{1}\right)^{\wedge} .5\right. \\
-\mathrm{F})\end{array}$ & 1.58 & 1.08 & 1.10 & 0.89 & 0.59 & 1.82 & 1.88 & 0.51 \\
\hline $\mathrm{h}^{2} / \mathrm{H}_{2}$ & 0.75 & 0.90 & 0.00 & 0.91 & 2.10 & 0.39 & 1.70 & 2.00 \\
\hline $\mathrm{r}$ & -0.22 & -0.58 & -0.13 & -0.19 & 0.55 & -0.46 & 0.17 & -0.16 \\
\hline Heritability (narrow sense) & 13.04 & 32.59 & 45.94 & 46.34 & 11.08 & 68.30 & 59.70 & 2.83 \\
\hline
\end{tabular}


The value of $(\mathrm{H} 1 / \mathrm{D})^{1 / 2}$ was higher $(10.80)$ indicating over-dominance. The proportion of genes with positive and negative effects $\left(\mathrm{H}_{2} / 4 \mathrm{H}^{1}\right)$ in parents was found to be 0.20 (less than 0.25 ), which denoted asymmetry at loci showing dominance. The proportion of dominance and recessive genes $\left[\left(4 \mathrm{DH}_{1}\right)^{1 / 2}+\mathrm{F} /\right.$ $\left.\left(4 \mathrm{DH}_{1}\right)^{1 / 2}-\mathrm{F}\right]$ was 1.88 . The number of group of genes $\left(\mathrm{h}^{2} / \mathrm{H}_{2}\right)$ exhibiting dominance and controlling the character was 1.70 . The narrow sense heritability (59.70\%) indicated that additive type of gene action played an important role in the inheritance of this trait.

A detailed knowledge about the magnitude and nature of genetic variation in a specific population is of prime importance for the effective prediction of the most effective breeding programme (Debnath, 1988). Diallel analysis is most balanced and systemic experimental design to examine continuous variation. The genetic information related to parental population becomes available quite in early generation i.e. in $F_{1}$ and it is thus useful to define breeding strategy without losing much time. In diallel cross system, there is no need for parents to be strictly inbred or to have uniformity. The knowledge of gene effects for different traits is of prime importance before starting a breeding programme. Determination of the most suitable breeding method and selection strategy for improvement of a trait would depend on the knowledge of gene actions operating in breeding population. In plant breeding, gene action is usually measured in terms of components of genetic variances or combining ability variances and effects. Since most of the characters, which showed heterosis, are governed by polygenes, the study of gene action (inheritance pattern) of these characters is of valuable importance in ascertaining the genetic basis of heterosis.

The results of diallel analysis of present study revealed over-dominance for all the characters (except node no of first female flower, average fruit weight, first fruit harvest, yield per plant) studied. In all these characters, the dominance component of genetic variance $\left(\mathrm{H}_{1}\right)$ was higher than the additive component of genetic variance (D) (except no of first fruit set, days to first fruit harvest and yield per plant) indicating predominance of dominant gene action over additive gene action. This was also confirmed by the values of narrow sense heritability which were found to be less than $50 \%$ for all the characters (except days to male flower, days to female flower, node no of first male flower, no of primary branches and vine length). The positive sign of ' $F$ ' value in most of the characters showed an excess of dominant genes in the parents. The proportion of genes with positive and negative effects $\left(\mathrm{H}_{2} / 4 \mathrm{H}_{1}\right)$ in parents was found to be less than 0.25 for all these characters denoting asymmetry at loci showing dominance.

The mean degree of dominance $\left(\mathrm{H}_{1} / \mathrm{D}\right)^{1 / 2}$ which was also found to be more than 1 for all the characters (except days to male flower, days to female flower, node to first male flower, no of first fruit set, and vine length confirmed the presence of over-dominance. In accordance to the findings, Munshi et al., (2006) reported predominance of non-additive genetic variance (over-dominance) and low narrow sense heritability for characters like days to first fruit harvest, number of fruits per plant and yield per plant. These results were also on conformity with the findings consonance of Pal et al., (2004) in bottle gourd and Kamer et al., (2015) in muskmelon. The results of the present investigation showed over-dominance for majority of the traits. The predominance of non-additive gene action and low to moderate narrow sense heritability for majority of the characters studied suggested that heterosis breeding might be advantageous to get higher gain in muskmelon. 
In conclusion, the results of present investigation revealed over-dominance for all the characters (except node no of first female flower, average fruit weight, first fruit harvest, yield per plant) studied. In all these characters, the dominance component of genetic variance $\left(\mathrm{H}_{1}\right)$ was higher than the additive component of genetic variance (D) (except no of first fruit set, days to first fruit harvest and yield per plant) indicating predominance of dominant gene action over additive gene action. Thus, in the present investigation, the predominance of nonadditive gene action and low narrow sense heritability was observed for most of the important yield contributing characters which suggested the importance of heterosis breeding to get higher gain in muskmelon.

\section{References}

Danin-Poleg, Y., Reis, N., Tzuri, G. and Katzir, N., 2001. Development and characterization of microsatellite markers in Cucumis. Theoretical and Applied Genetics, 102(1), pp.61-72.

Debnath, S.C. 1988. Nature and estimation of genetic components of variation. Acta Agronomica Hungarica, 37: 337-351.

Decker-Walters, D.S., Chung, S.M., Staub, J.E., Quemada, H.D. and López-Sesé, A.I., 2002. The origin and genetic affinities of wild populations of melon (Cucumis melo, Cucurbitaceae) in North America. Plant Systematics and Evolution, 233(3-4), pp.183-197.

Hayman, B.I., 1954. The theory and analysis of diallel crosses. Genetics, 39(6), pp.789-809.
Kamer Abou., Mona, M.E. and El-Gamal, A.M. 2015. Heterosis and Heritability studies for fruit characters and yield in melon (Cucumis melo L.). Middle East Journal of applied Sciences, 5(1):262273.

Mliki, A., Staub, J.E., Zhangyong, S. and Ghorbel, A., 2001. Genetic diversity in melon (Cucumis melo L.): an evaluation of African germplasm. Genetic resources and crop evolution, 48(6), pp.587-597.

Munshi, A.D., Kumar, R. and Panda, B., 2006. Studies on genetic components of variation in cucumber (Cucumis sativus L.). Indian Journal of Horticulture, 63(2), pp.213-214.

Pal, S.N., Ram, D., Pal, A.K. and Singh, G., 2004. Combining ability studies for certain metric traits in bottle gourd [Lagenaria siceraria (Mol.) Standl.]. Indian Journal of Horticulture, 61(1), pp.46-50.

Sebastian, P., Schaefer, H., Telford, I.R. and Renner, S.S., 2010. Cucumber (Cucumis sativus) and melon (C. melo) have numerous wild relatives in Asia and Australia, and the sister species of melon is from Australia. Proceedings of the National Academy of Sciences, 107(32), pp.14269-14273.

Singh, A.K., Gautam, N.C. and Singh. R.D.1998. Studies on combining ability in cucumber (Cucumis sativus L.). Prog. Hort. 30 (3-4):204-10.

Walton, P.D., 1968. The genetics of geotaxis in Drosophila melanogaster. Canadian Journal of Genetics and Cytology, 10(3), pp.673-687.

\section{How to cite this article:}

Koushik Saha, Subhalaxmi Mishra, H. Choudhary and Sourav Mahapatra. 2018. Estimates of Genetic Component of Variation in Muskmelon (Cucumis melo L.). Int.J.Curr.Microbiol.App.Sci. 7(07): 1144-1151. doi: https://doi.org/10.20546/ijcmas.2018.707.138 